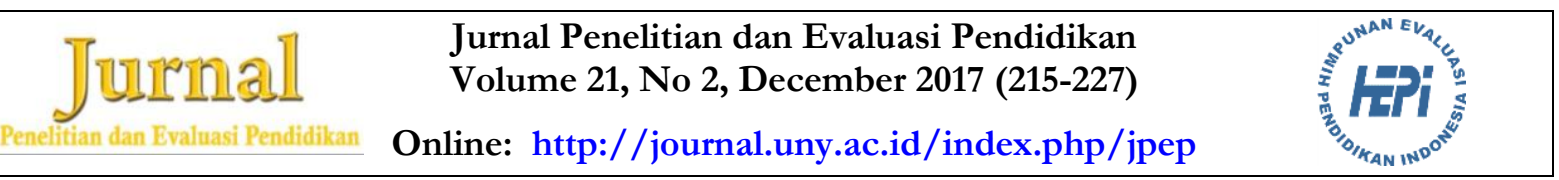

\title{
EVALUASI IMPLEMENTASI KEBIJAKAN SEKOLAH MENENGAH KEJURUAN PROGRAM 4 TAHUN DALAM MENINGKATKAN EMPLOYABILITYLULUSAN
}

\author{
Soenarto ${ }^{1 *}$, Muhammad Mustaghfirin Amin ${ }^{2}$, Kumaidi ${ }^{3}$ \\ ${ }^{1}$ Univ. Negeri Yogyakarta, ${ }^{2}$ Direktorat PSMK Kemdikbud, ${ }^{3}$ Univ. Muhammadiyah Surakarta \\ 1J1. Colombo No. 1, Depok, Sleman 55281, Yogyakarta, Indonesia, ${ }^{2}$ Kompleks Kemdikbud, Jakarta \\ Pusat 10270, Indonesia, 3Jl. A. Yani, Mendungan, Pabelan, Kartasura, Sukoharjo, Jawa Tengah 57162 \\ * Corresponding Author. Email: soenarto@uny.ac.id
}

\begin{abstract}
Abstrak
Penelitian ini merupakan penelitian evaluasi menggunakan model CIPPO (context, input, process, product, and outcomes) yang bertujuan mengungkapkan tingkat employability lulusan SMK 4 tahun dengan menggunakan SMK 3 tahun sebagai base line. Sampel penelitian adalah delapan SMK 4 tahun dan delapan SMK 3 tahun dengan melibatkan 544 orang sebagai subyek penelitian. Pengumpulan data menggunakan metode observasi, kuesioner, wawancara, dan dokumentasi, kemudian dianalisis secara kuantitatif menggunakan statistik deskriptif. Hasil penelitian menunjukkan: (1) Kurikulum SMK 4 tahun dan 3 tahun menggunakan kurikulum nasional yang dikembangkan berdasarkan kebutuhan Dunia Usaha Dunia Industri (DU/DI); (2) Kompetensi lulusan SMK 4 tahun seluruhnya berkategori sangat baik, sedangkan SMK 3 tahun 64\% sangat baik; (3) menurut DU/DI, lulusan SMK 4 tahun unggul dalam kedisiplin, keuletan, kemampuan teori, kemampuan praktek, rasa percaya diri, ketelitian, kreativitas, dan kepemimpinan; (4) Kompetensi guru SMK 4 tahun unggul dalam membimbing siswa, menghasilkan bahan ajar, mengembangkan bengkel, dan membangun kerja sama dengan DU/DI; (5) sarana dan prasarana SMK 3 dan 4 tahun memiliki kemiripan kondisi; (6) pembiayaan SMK 4 tahun melibatkan alumni sedangkan SMK 3 tahun tidak; (7) Kecepatan mendapat pekerjaan, jumlah lulusan yang bekerja, dan penghasilan lulusan SMK 4 tahun lebih baik dari pada SMK 3 tahun; dan (8) Kepuasan kerja lulusan SMK 4 tahun lebih baik daripada lulusan SMK 3 tahun.
\end{abstract}

Kata kunci: evaluasi, kebijakan, SMK, employability lulusan

\section{EVALUATION OF THE IMPLEMENTATION OF 4-YEAR PROGRAM POLICY OF VOCATIONAL SECONDARY SCHOOL IN IMPROVING GRADUATES' EMPLOYABILITY}

\begin{abstract}
The aim of this research is to disclose the employability level of 4-year Vocational Secondary School (or Sekolab Menengah Kejuruan (SMK)) graduates by using 3-year SMK as the base-line. This research is an evaluation research using CIPPO (context, input, process, product, and outcomes) model. The sample of the research is eight 4-year SMK and eight 3-year SMK, and it involves 544 persons as the research subjects. The data were collected by observation, questionnaire, interview and documentation, and analyzed quantitatively by using descriptive statistic analysis. The research result shows that: (1) 4-year and 3-year SMKs are using national curriculum developed based on the needs of Bussiness \& Insdustrial Performer (DU/DI), (2) the competency of all (100\%) the 4year SMK graduates are 'very good', while only 64\% 3-year SMK graduates is 'very good', (3) based on DU/DI's stand point, the 4-year SMK graduates is better in 8 aspects (discipline, tenacuty, theoretical knowledge, practical skill, self-independence, carefullness, creativity and leadership), (4) 4-year SMK teacher is better in guiding the students, producing learning material, developing workshop, and cooperating with DU/DI, (5) 4-year SMK has similiar condition of facilities with 3-year SMK, (6) 4-year SMK funding system is better than the 3-year SMK by involving the alumni, (7) 4-year SMK graduate is better in number of working graduates, income, and speed to get jobs, (8) 4-year SMK graduate are more satisfied with their job than the 3-year graduate.
\end{abstract}

Keywords: evaluation, policy, employability level of vocational secondary school

Permalink/DOI: http:/ / dx.doi.org/10.21831/pep.v21i2.17076

Jurnal Penelitian dan Evaluasi Pendidikan

ISSN 1410-4725 (print) ISSN 2338-6061 (online) 


\section{Pendahuluan}

Produk lembaga pendidikan adalah sumber daya manusia yang memiliki kompetensi untuk mengelola sumber daya alam dan sumber daya lainnya secara efektif dan efisien untuk kesejahteraan masyarakat. Lembaga pendidikan harus selalu melakukan pembaharuan agar produk yang dihasilkan memenuhi kebutuhan masyarakat.

Persaingan bebas dalam pasar terbuka di wilayah negara-negara ASEAN (Association of South East Asian Nations) telah dimulai satu dasawarsa sejak diberlakukannya Asean Free Trade Area (AFTA) pada 2003 dan pada tahun 2015 ini memasuki Masyarakat Ekonomi ASEAN (MEA). Dunia usaha dan dunia industri (DU/DI) harus melakukan berbagai inovasi di segala bidang agar dapat menghasilkan produk berkualitas dengan harga terjangkau, dan dapat bersaing secara global. Dalam rangka menghasilkan produk yang berkualitas dengan harga terjangkau, diperlukan tenaga kerja yang mempunyai kemampuan inovatif dan kreatif. Hal ini mencakup tantangan terhadap sekolah kejuruan yang harus mampu menghasilkan lulusan yang memiliki kompetensi yang dibutuhkan DU/DI.

Banyak pihak menghawatirkan ketidaksiapan Indonesia dalam menghadapi MEA. Kawasan ASEAN akan menjadi pasar terbuka dan kesatuan yang berbasis produksi serta mobilitas arus barang, jasa, investasi, modal, dan tenaga kerja terampil akan bergerak bebas. Sementara itu daya saing bangsa yang dinilai tidak cukup terutama karena sumber daya manusia (SDM) yang tidak cukup kompetitif dibanding negara-negara lain di ASEAN. Dilihat dari kependudukan, ketenagaan, dan sumber daya manusia, tantangan dalam menghadapi liberalisasi perdagangan termasuk Masyarakat Ekonomi ASEAN menurut Alisjahbana (2014) ada tiga aspek yaitu (1) menjaga momentum demografi, (2) meningkatkan partisipasi angkatan kerja, dan (3) meningkatkan produktivitas tenaga kerja.

Sejarah ekonomi dunia menyuguhkan fakta bahwa bonus demografi ikut mendorong pertumbuhan ekonomi yang maju seperti yang dalami oleh Asian Tiger (Korea Selatan, Singapura, Taiwan) dan negara-negara BRIC (Brazil, Rusia, India dan China). Keuntungan ini akan diperoleh jika partisipasi tenaga kerja tinggi dan produktifitas tenaga kerja juga tinggi. Peningkatan partisipasi tenaga kerja atau menurunkan tingkat pengangguran harus terus diupayakan. Iklim ketenagakerjaan perlu didorong untuk menciptakan pasar tenaga kerja yang fleksibel dan efisien serta kemudahan investasi.

Jumlah penduduk usia produktif yang besar saja tidak cukup untuk menghadapi persaingan baik dalam skala regional maupun internasional. Perlu adanya peningkatan daya saing penduduk usia produktif sebagai sebuah competitive advantage. Pelaksanaan Program Pendidikan Menengah Universal dan penguatan pendidikan tinggi tentunya akan sangat berperan untuk menyediaan tenaga terampil yang lebih banyak, tetapi jaminan kualitas dan relevansi menjadi bagian yang harus dilaksanakan sejalan dengan peningkatan aksesnya. Berbagai standar kompetensi keterampilan dan kualifikasi kerja yang diamanatkan dalam road map MEA perlu segera diselesaikan.

Upaya nyata peningkatan kualitas tenaga kerja melalui pendidikan, pre-service maupun in-service training termasuk pendidikan non-formal, termasuk berbagai pelatihan oleh dunia usaha sangat penting untuk ditingkatkan. Hal ini selaras dengan penelitian Barro (2001, p. 13) yang mengungkap peran pendidikan dalam menentukan pertumbuhan ekonomi dengan memasukkan variabel pendidikan yang diproksi dengan quantity and quality of schooling. Hasil penelitiannya menunjukkan bahwa baik quantity maupun quality of schooling berpengaruh terhadap pertumbuhan ekonomi, namun quality of schooling memiliki pengaruh yang lebih dominan dibandingkan variabel lain.

Akhir tahun 2015 MEA mulai diberlakukan, secara otomatis akan terjadi liberalisasi di semua bidang. Salah satunya adalah bidang jasa yang menyangkut penempatan SDM, karena sumber daya manusia merupakan faktor penentu keunggulan dalam persaingan nasional dan global (Habibie, 2013). 
Salah satu usaha untuk meningkatkan kualitas dan relevansi pendidikan adalah mengembangkan sekolah kejuruan, karena tenaga kerja yang banyak dibutuhkan adalah setingkat teknisi lulusan sekolah kejuruan. Sebagaimana yang diungkapkan oleh Balogh (1969, p. 259) bahwa sekolah kejuruan dapat mengatasi masalah-masalah di negara berkembang yang menekankan bahwa sebagai faktor penentu kemakmuran dan kemajuan sosio-ekonomi, pendidikan harus bersifat teknis, kejuruan, dan demokratis. Lebih lanjut lagi, penelitian Psacharopoulos (1997, p. 385) menemukan fakta bahwa negara-negara berkembang berusaha membenahi dirinya menjadi negara industri dimana industrialisasi mensyaratkan teknologi yang membutuhkan tenaga kerja (hard skill) sebagai operatornya. Hal ini berarti bahwa penyediaan sekolah kejuruan untuk menghasilkan keterampilan yang diperlukan menjadi sangat penting.

Undang-Undang Nomor 20 Tahun 2003 tentang Sistem Pendidikan Nasional (Depdiknas, 2003) mengamanahkan bahwa pendidikan kejuruan merupakan pendidikan yang mempersiapkan peserta didik untuk bekerja dalam bidang tertentu. Djojonegoro (1998, p. 36) mendeskripsikan pendapat Rupert Evans bahwa pendidikan kejuruan adalah pendidikan yang bertujuan untuk: (1) memenuhi kebutuhan masyarakat akan tenaga kerja, (2) meningkatkan pilihan pendidikan bagi setiap individu, dan (3) menumbuhkan motivasi untuk belajar sepanjang hayat. Artinya, pendidikan kejuruan adalah pendidikan untuk bekerja di bidang tertentu, yaitu yang lulusannya dibutuhkan oleh DU/DI. Pernyataan tersebut didukung oleh Pardjono, Sugiyono, \& Budiyono (2015) yang mengungkapkan bahwa "vocational education cannot be removed from existing workforce development".

Pendidikan kejuruan harus selalu menyesuaikan diri dengan kebutuhan masyarakat khususnya kebutuhan industri. Sekolah Menengah Kejuruan (SMK) harus menjalin kerja sama dengan dunia industri dan dunia usaha sebagai pengguna lulusan. Pendidikan kejuruan harus didesain agar para lulusan memiliki keterampilan, kemampuan, pengetahuan, sikap, dan kebiasaan kerja yang sesuai dengan kebutuhan dunia kerja.

SMK sebagai lembaga pendidikan tingkat menengah yang bertujuan menghasilkan lulusan yang memiliki pengetahuan, keterampilan, akhlak dan sikap yang berstandar nasional dan global perlu terus ditingkatkan dan dikembangkan. Pengembangan sekolah menjadi tanggungjawab bersama antara sekolah sebagai penyelenggara pendidikan, masyarakat sebagai sasaran pendidikan, industri sebagai pemakai tenaga kerja lulusan SMK, dan Direktorat Pembinaan SMK sebagai lembaga pemerintah yang berfungsi sebagai pembina dan penentu kebijakan.

Data pengangguran terbuka yang berasal dari berita resmi Badan Pusat Statistik pada tahun 2014 menunjukkan bahwa jumlah penganggur terbuka yang berasal dari SMK cukup tinggi, yaitu 2,179 juta orang atau 15,15\% pada bulan Agustus 2014 (Badan Pusat Statistik, 2014). Apabila kondisi ini tidak segera diatasi akan dapat menyebabkan keprihatinan yang serius, karena dari tahun ke tahun jumlah kecenderungan pengangguran terbuka semakin meningkat.

Pada tahun 1970 dalam Program Pembangunan Lima Tahun ke satu (PELITA I), pemerintah mendirikan suatu lembaga sekolah teknik tingkat menengah melalui sebuah proyek yang diberi nama "Proyek Perintis Sekolah Teknologi Menengah Pembangunan" dengan masa studi lebih lama dibanding standar SMA atau SMK lainya. Lama pendidikan di lembaga ini 4 tahun. Lembaga itu dikenal dengan nama Perintis STM Pembangunan.

Misi didirikannya Proyek Perintis STM Negeri Pembangunan yaitu: (1) merintis pembaharuan sistem pendidikan teknik tingkat menengah dengan melakukan penyempuranaan kurikulum, perbaikan sistem pembelajaran dan asesmen pembelajaran, peningkatan kompetensi guru, pemenuhan sarana dan prasarana, bimbingan karir, dan menjalin hubungan dengan DU/DI; (2) meningkatkan efektivitas dan efisiensi melalui penggunaan sumber daya manusia dan 
sumber dana baik fisik maupun non-fisik dioperasikan seoptimal mungkin, serta segala sarana dan prasarana yang tersedia dapat dioperasikan dengan pencapaian tujuan pendidikan yang lebih baik.

Proyek perintis STM Pembangunan harus dapat menghasilkan lulusan yang memiliki mutu yang sesuai dengan kebutuhan dunia industri yang ada di Indonesia. Dalam rangka mendukung program STM Negeri Pembangunan, Direktorat Pembinaan SMK telah melakukan penyempurnaan kurikulum, perbaikan sistem pembelajaran dan penilaian, peningkatan jumlah dan kompetensi guru, pemenuhan sarana dan prasarana, dan menjalin hubungan kerja sama dengan DU/DI

Kurikulum sekolah kejuruan mengacu pada prinsip kurikulum berbasis kompetensi, hal ini dimaksudkan untuk memenuhi kebutuhan tenaga kerja namun belum sepenuhnya terpenuhi. Salah satu buktinya yakni lulusan sekolah kejuruan belum memiliki kompetensi memadai, menciptakan pengangguran, sementara kesempatan kerja banyak yang masih kosong (Supriadi, 2002, p. 612). Dalam waktu yang bersamaan terdapat juga lulusan STM/SMK 3 tahun yang juga bersaing untuk memasuki dunia usaha dan dunia industri. Perbedaan masa belajar dan pengalaman, memungkinkan kedua program SMK tersebut untuk memiliki kualitas lulusan yang berbeda pula. Perbedaan kualitas lulusan berdampak terhadap kesempatan kerja, kinerja lulusan, dan pengakuan DU/DI terhadap lulusan.

Oleh karena itu perlu dilakukan studi lanjut tentang dampak dari perbedaan masa belajar pada SMK program 4 tahun dan 3 tahun untuk mengetahui efektifitas kebijakan program SMK 4 tahun jika dibandingkan dengan program SMK 3 tahun. Perlu dilakukan evaluasi terhadap kompetensi lulusan dan kinerja SMK 3 tahun maupun SMK 4 tahun, sehingga dapat diketahui tingkat ketercapaian program yang sedang berjalan, yang selanjutnya digunakan untuk menyusun program dengan prinsip evaluasi yang berkelanjutan.

\section{Metode Penelitian}

Penelitian ini termasuk penelitian evaluasi yang bertujuan untuk mengevaluasi kinerja lulusan SMK 4 tahun dan SMK 3 tahun. Model evaluasi yang digunakan yakni CIPPO (context, input, process, product, dan outcomes).

Penelitian ini dilaksanakan di 8 SMK 4 tahun dan 8 SMK 3 tahun di Indonesia pada tahun 2016. Delapan SMK 4 tahun yang digunakan sebagai sampel merupakan keseluruhan SMK rintisan "Proyek Perintis Sekolah Teknologi Menengah Pembangunan" dengan masa studi 4 tahun. Delapan SMK 3 tahun dipilih menggunakan purposive sampling mempertimbangkan kesamaan karakteristik daerah dengan SMK 4 tahun.

Subjek penelitian mencakup pihakpihak yang berhubungan langsung dengan terselenggaranya SMK program 4 tahun dan 3 tahun. Secara rinci, subjek penelitian ini terdiri atas kepala sekolah, wakil kepala sekolah, ketua program keahlian, koordinator BKK, koordinator BP, Tim ISO, guru, siswa, alumni, komite sekolah untuk SMK 4 tahun dan 3 tahun, dan DU/DI sebagaimana disajikan dalam Tabel 1.

Tabel 1. Subjek Penelitian

\begin{tabular}{llccc}
\hline No Subjek Penelitian & $\begin{array}{c}\text { SMK 4 } \\
\text { tahun }\end{array}$ & $\begin{array}{c}\text { SMK 3 Jumlah } \\
\text { tahun }\end{array}$ & J \\
\hline 1 Kepala Sekolah & 8 & 8 & 16 \\
2 & Wakil Kepala Sekolah & 32 & 32 & 64 \\
3 & Ketua Program keahlian & 40 & 40 & 80 \\
4 & Koordinator Bursa & 8 & 8 & 16 \\
& Kerja Khusus/BKK & & & \\
5 & Koordinator Bimbingan & 8 & 8 & 16 \\
& Penyuluhan/BP & & & \\
6 & Tim ISO & 8 & 8 & 16 \\
7 & Guru & 40 & 40 & 80 \\
8 & Siswa & 40 & 40 & 80 \\
9 & Alumni & 40 & 40 & 80 \\
10 & DUDI & 40 & 40 & 80 \\
11 & Komite Sekolah & 8 & 8 & 16 \\
& Jumlah & 272 & 272 & 544 \\
\hline
\end{tabular}


Pengumpulan data kuantitatif dikumpulkan dengan menggunakan kuesioner dan dokumentasi, sedangkan data kualitatif diperoleh dengan wawancara dan observasi. Kuesioner digunakan untuk mengungkap data tentang kinerja lulusan SMK 4 tahun dan SMK 3 tahun. Observasi di sekolah dilakukan untuk mengetahui kinerja guru di kelas di laboratorium, di bengkel, keberadaan dan keberfungsian sarana prasarana, proses pembelajaran di kelas, laboratorium, dan bengkel. Observasi di industri dilakukan untuk mengetahui kinerja lulusan SMK 4 tahun dan 3 tahun di DU/DI. Wawancara digunakan untuk memperoleh data kualitatif yang berupa kepuasan kerja, pengakuan kompetensi lulusan dari industri, dan etika kerja lulusan, dan proses pembelajaran di kelas, laboratorium, dan bengkel. Dokumentasi digunakan untuk mengumpulkan data tentang kondisi geografis, landasan hukum, kebijakan, prestasi akademik, animo, dan serapan lulusan.

Instrumen penelitian yang digunakan yakni kuesioner dengan empat skala (4= sangat baik, 3 = baik, 2 tidak baik, 1 = sangat tidak baik), pedoman observasi, dan pedoman wawancara. Pengembangan instrumen penelitian dilakukan melalui kegiatan FGD melibatkan pakar, praktisi pendidikan kejuruan, dan para pemangku kepentingan. Validitas konstruk kuesioner dengan menggunakan analisis faktor eksploratori menunjukkan bahwa kuesioner untuk mengungkap process, product, dan outcomes termasuk kategori valid. Pedoman wawancara dan pedoman observasi dibuktikan validitasnya dengan expert judgment. Estimasi reliabilitas kuesioner dengan menggunakan formula Cronbach Alpha diperoleh hasil 0,82 yang mengindikasikan reliabilitas kuesioner sangat tinggi.

Data kuantitatif yang diperoleh dari kuesioner dan dokumentasi dianalisis dengan menggunakan statistik deskriptif yang berupa nilai tendensi sentral kemudian disajikan dalam bentuk tabel dan diagram. Data kualitatif yang diperoleh dari wawancara dan observasi digunakan untuk menguatkan temuan deskriptif kuantitatif.
Kriteria evaluasi untuk analisis data disajikan pada Tabel 2.

Tabel 2. Dampak Program SMK 3 tahun dan 4 tahun

\begin{tabular}{ll}
\hline Skor & Keterangan \\
\hline $81-100$ & Sangat Baik \\
$70-80$ & Baik \\
di bawah 70 & Tidak baik \\
\hline
\end{tabular}

\section{Hasil Penelitian dan Pembahasan}

Hasil

Kurikulum yang diterapkan pada SMK program 3 tahun tidak jauh berbeda dengan SMK program 4 tahun. SMK program 3 tahun juga menggunakan kurikulum nasional yang dikembangkan sesuai dengan kebutuhan DU/DI. Kerja sama SMK 4 tahun dan 3 tahun dengan industri pada dasarnya hampir sama, namun lama Program Kerja Lapangan (PKL) siswa SMK 4 tahun lebih lama daripada SMK 3 tahun sehingga kompetensi lulusan SMK 4 tahun lebih baik.

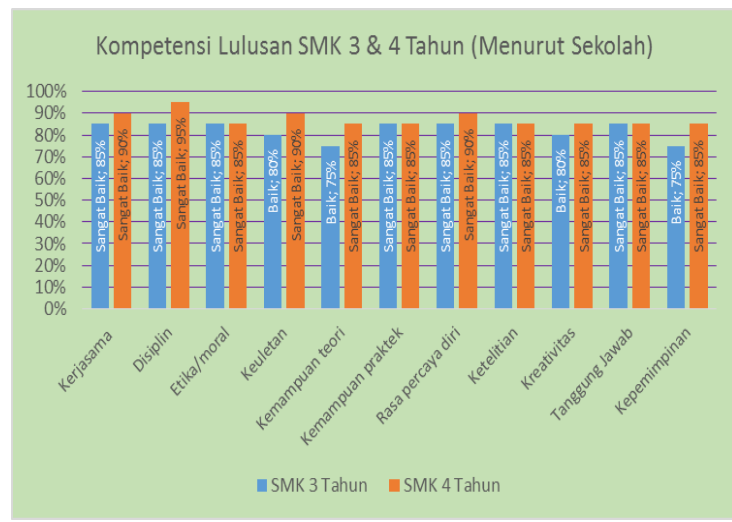

Gambar 1. Kompetensi Lulusan SMK 3 tahun dan 4 tahun

Kompetensi lulusan kualitas lulusan menurut sudut pandang sekolah. Kompetensi lulusan dinilai melalui 11 aspek yaitu: (1) kerja sama, (2) disiplin, (3) etika/moral, (4) keuletan, (5) kemampuan teori, (6) kemampuan praktik, (7) rasa percaya diri, (8) ketelitian, (9) kreativitas, (10) tanggung jawab, dan (11) kepemimpinan. Gambar 1 menunjukkan perbandingan kompetensi lulusan SMK program 4 tahun SMK program 
3 tahun. Berdasarkan sebelas kompetensi yang dinilai, SMK 4 tahun memiliki tujuh keunggulan daripada SMK 3 tahun yakni kerja sama, disiplin, keuletan, kemampuan teori, rasa percaya diri, kreativitas, dan kepemimpinan. Empat kompetensi lainnya memiliki persentase yang sama dan tidak ada kompetensi yang lebih rendah dari pada SMK 3 tahun.

Kinerja lulusan SMK merupakan kualitas performa lulusan ditinjau dari sudut pandang DU/DI sebagai pengguna lulusan. Aspek yang diamati meliputi kerja sama, kedisiplinan, etika/moral, keuletan, kemampuan teori, kemampuan praktek, rasa percaya diri, ketelitian, kreativitas, kepemimpinan dan tanggung jawab. DU/DI menilai 36\% lulusan SMK 4 tahun memiliki kinerja yang sangat baik dan sisanya $64 \%$ berada pada level baik. Sementara itu seluruh (100\%) lulusan SMK program 3 tahun memiliki kinerja yang baik dan tidak ada yang berada pada level sangat baik.

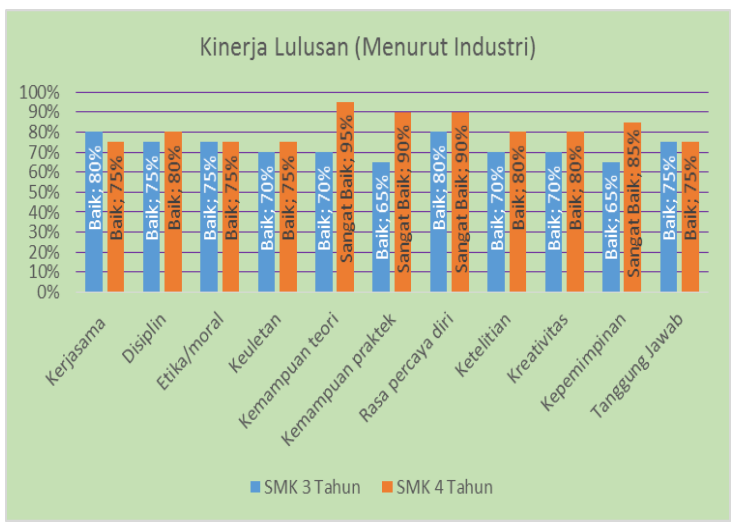

Gambar 2. Kinerja Lulusan SMK 3 tahun dan 4 tahun

Perbandingan kinerja lulusan SMK 3 tahun dengan SMK 4 tahun disajikan pada Gambar 2. Menurut pandangan DU/DI, lulusan SMK 4 tahun memiliki keunggulan dibandingkan lulusan SMK 3 tahun, yaitu dalam hal disiplin, keuletan, kemampuan teori, kemampuan praktik, rasa percaya diri, ketelitian, kreativitas, dan kepemimpinan.

Kompetensi guru di SMK program 4 tahun dan SMK 3 tahun ditinjau dari persepsi siswa, kepala sekolah dan wakil kepala sekolah. Data kompetensi guru dilihat dari aspek cara mengajar teori, mengajar praktik, disiplin mengajar, kehadiran mengajar, kemampuan membimbing karir siswa, serta kemampuan guru dalam membimbing belajar siswa diperoleh dari respon siswa.

Menurut siswa 33\% guru yang mengajar pada SMK program 4 tahun memiliki kompetensi yang sangat baik, sedangkan 67\% guru berada dalam level baik. Kondisi ini tidak lebih lebih baik jika dibandingkan dengan hasil pendapat siswa mengenai kompetensi gurunya pada SMK program 3 tahun dimana $67 \%$ guru termasuk dalam kategori sangat baik dan 33\% lainnya berada pada kategori baik. Secara rinci, kondisi masing-masing aspek kompetensi guru menurut siswa untuk SMK program 4 tahun dan SMK program 3 tahun disajikan pada Gambar 3.

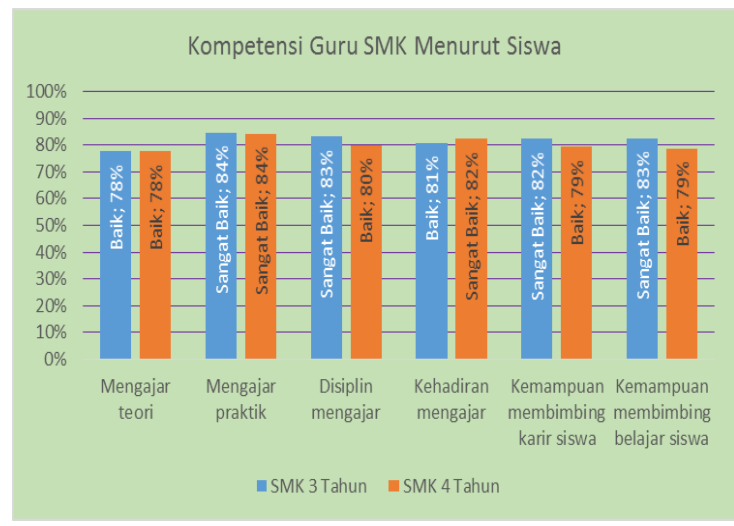

Gambar 3. Kompetensi Guru SMK menurut Siswa

Menurut Kepala sekolah dan wakil kepala sekolah, antara SMK program 4 tahun dengan SMK program 3 tahun memiliki guru dengan kompetensi yang sama. Sebagian besar aspek kompetensi guru pada kategori sangat baik dan baik. Namun masih ada guru yang terindikasi memiliki aspek kompetensi yang tidak baik yaitu sebesar 11\%. Sebagian besar kompetensi guru menurut kepala sekolah dan wakil kepala sekolah pada masing-masing aspek berada pada kondisi yang sama antara SMK program 4 tahun dan SMK 3 tahun sebagaimana disajikan pada Gambar 4. 


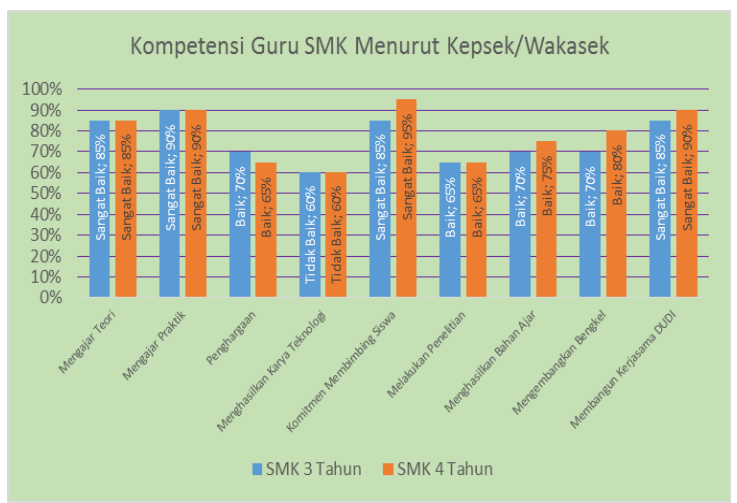

Gambar 4. Kompetensi guru SMK menurut Kepala Sekolah dan Wakil Kepala Sekolah

Berkaitan dengan sarana dan prasarana difokuskan pada dua hal utama, yaitu kualitas sarana dan prasarana yang dimiliki yang ditunjukan oleh 11 indikator (ruang kelas teori, laboratorium, bengkel, lahan praktikum, teaching factory, bengkel kerja sama industri, tempat uji kompetensi (TUK), peralatan uji kompetensi, bahan praktikum) dan persentase pemenuhan kebutuhan atas sarana dan prasarana. Kondisi sarana dan prasarana pada SMK program 4 tahun sebagaimana disajikan pada Gambar 5 menunjukkan bahwa $80 \%$ berada dalam kategori baik dan 20\% dengan kategori cukup baik. Sementara itu kondisi sarana dan prasarana SMK program 3 tahun yang disajikan pada Gambar 6 menunjukan bahwa $60 \%$ sarana dan prasarana dalam kategori baik, 20\% dalam kategori cukup baik dan 20\% sisanya dalam kategori kurang baik. Secara umum kualitas sarana dan prasarana untuk kedua SMK dinyatakan baik. Data menunjukan bahwa SMK 4 memiliki sarana dan prasarana yang lebih terawat dan berkualitas baik. Kebutuhan sarana dan prasarana SMK 4 tahun sudah mencukupi dengan persentase $75 \%$. Sarana dan prasarana SMK 3 tahun menunjukan bahwa 80\% cukup dan 20\% tidak cukup.

Pembiyaan SMK berasal dari berbagai sumber dana yang berfungsi untuk membantu kelancaran program pendidikan. SMK program 4 tahun dan 3 tahun memiliki sumber dana yang berasal dari berbagai instansi baik swasta maupun instansi pemerintah seperti dana BOS, bantuan gubernur, komite sekolah, SMK rujukan, bantuan pemerintah propinsi, bantuan pemerintah daerah, dan beasiswa alumni. SMK 4 tahun menerima bantuan dari pemerintah daerah, gubernur, dan dari alumni, sedangkan SMK 3 tahun tidak menerima bantuan dari lembaga tersebut. Hal ini menunjukan besarnya bantuan pemerintah dan partisipasi alumni terhadap SMK 4 tahun.

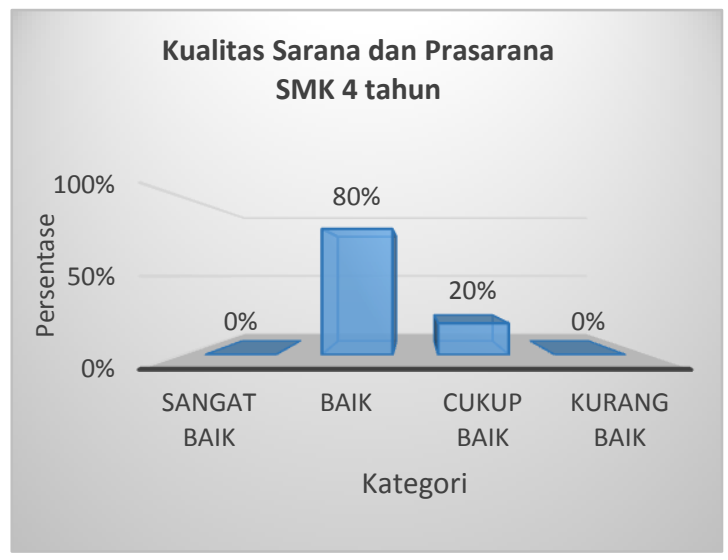

Gambar 5. Kualitas Sarana dan Prasarana SMK 4 tahun

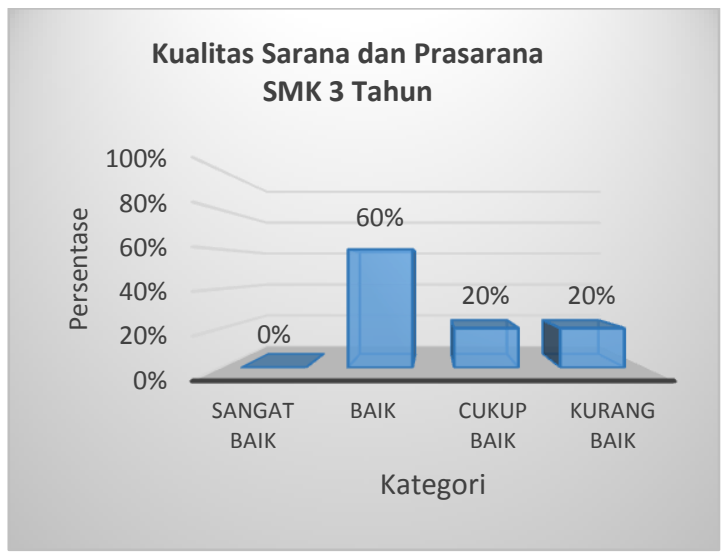

Gambar 6. Kualitas Sarana dan Prasarana SMK 3 tahun

Dampak penyelenggaraan SMK dapat dilihat pada kondisi lulusannya, yaitu baik yang bekerja, berwirausaha, maupun melanjutkan program pendidikan di perguruan tinggi serta lamanya waktu tunggu kerja mahasiswa. Data masing-masing aspek yang berhubungan dengan dampak program SMK 3 tahun dan SMK 4 tahun disajikan pada Tabel 3. 
Tabel 3. Dampak Program SMK 3 tahun dan 4 tahun

\begin{tabular}{lcc}
\hline SMK & 3 Tahun & 4 Tahun \\
\hline Lulusan Bekerja & $61 \%$ & $71 \%$ \\
Lulusan Berwirausaha & $7 \%$ & $6 \%$ \\
Melanjutkan Studi & $12 \%$ & $14 \%$ \\
Lain-lain & $20 \%$ & $9 \%$ \\
Masa Tunggu Kerja (bln) & $0-12$ & $0-3$ \\
Gaji Bulan 1 & $1-2,5$ jt & $1,1-5$ jt \\
\hline
\end{tabular}

Tabel 3 menunjukkan bahwa bila ditinjau dari jumlah lulusan yang bekerja, lulusan SMK program 4 tahun cenderung memiliki jumlah lulusan yang bekerja lebih banyak, yaitu $71 \%$. Jumlah ini lebih tinggi dibanding lulusan dari program SMK 3 tahun yaitu 61\%. Ditinjau dari jumlah lulusan yang berwirausaha, antara SMK 3 tahun maupun SMK 4 tahun memiliki jumlah yang hampir sama, yaitu sebanyak 7\% dari jumlah keseluruhan lulusan SMK 3 tahun dan sebanyak $6 \%$ dari jumlah lulusan dari program SMK 4 tahun, meskipun dari SMK 3 tahun lebih tinggi.

Apabila dilihat dari lulusan yang melanjutkan studi ke perguruan tinggi, lulusan dari SMK program 3 tahun berkisar 12\% dari jumlah keseluruhan lulusan. Jumlah ini lebih sedikit dari persentase lulusan yang melanjutkan studi di perguruan tinggi dari SMK program 4 tahun yaitu berkisar 14\% dari jumlah lulusannya.

Ditinjau dari masa tunggu kerja, lulusan dari SMK program 4 tahun memiliki masa tunggu yang lebih pendek, yaitu 0-3 bulan. Nilai ini jauh lebih rendah dibandingkan dengan masa tunggu untuk lulusan SMK program 3 tahun, yaitu berkisar 0-12 bulan. Artinya, bila ditinjau dari masa tunggu kerjanya, lulusan SMK 4 tahun lebih baik dibandingkan dengan SMK 3 tahun. Hal ini juga terkait dengan kondisi gaji pada bulan pertama untuk karyawan lulusan SMK 4 tahun lebih tinggi daripada gaji untuk karyawan dari lulusan SMK 3 tahun. Lulusan SMK 4 tahun mendapat gaji Rp1.100.00,00 sampai Rp5.000.000,00, sedangkan lulusan SMK 3 tahun mendapat gaji Rp1.000.000,00 sampai Rp2.500.000,00.
Kepuasan kerja lulusan diamati berdasarkan 9 aspek yaitu penghasilan, suasana kerja, hubungan dengan atasan, hubungan sesama teman, keinginan pindah kerja, kepuasan kerja, fasilitas kerja, lingkungan kerja, dan jaminan kesehatan. Kepuasan kerja lulusan SMK 3 tahun dan 4 tahun menurut alumni disajikan pada Gambar 7.

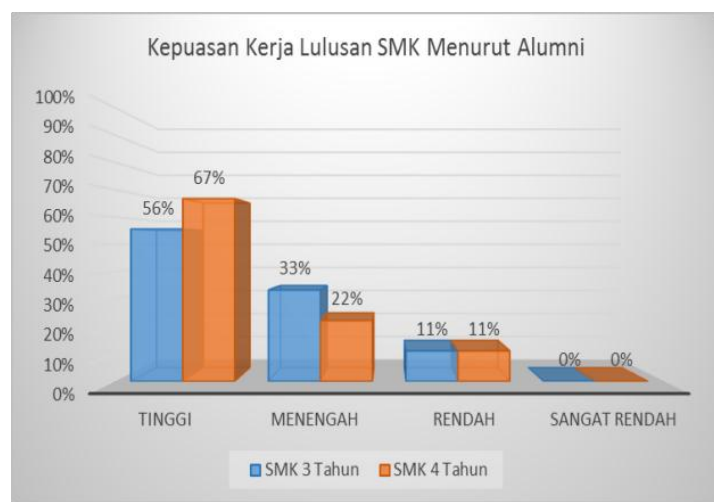

Gambar 7. Kepuasan Kerja Lulusan SMK menurut Alumni

Kepuasan kerja lulusan SMK 4 tahun adalah $67 \%$ pada kategori tinggi, 22\% pada kategori menengah, dan 11\% pada kategori rendah, sedangkan kepuasan kerja lulusan SMK 3 tahun dari 9 aspek yang diamati menunjukkan bahwa 56\% pada kategori tinggi, $33 \%$ pada kategori menengah, dan 11\% pada kategori rendah. Secara lebih rinci, kepuasan kerja lulusan disajikan pada Gambar 8.

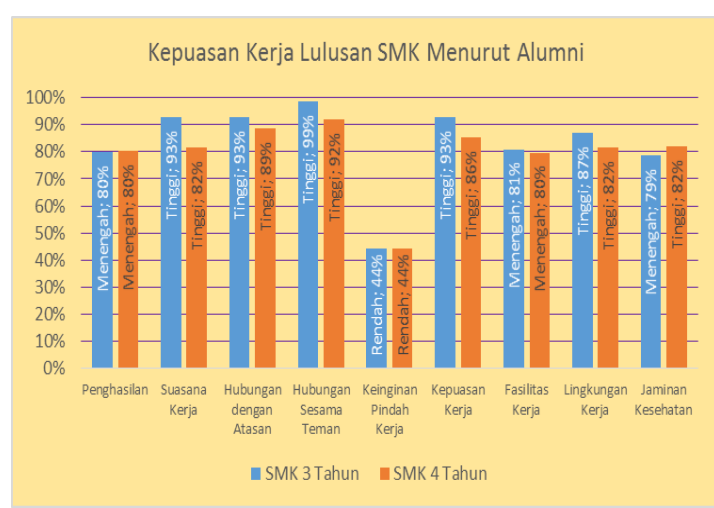

Gambar 8. Kepuasan Kerja Lulusan SMK dilihat per Aspek

Gambar 8 menunjukkan bahwa pada aspek penghasilan dan fasilitas kerja, baik lulusan SMK 3 tahun maupun 4 tahun memiliki tingkat kepuasan pada kategori mene- 
ngah. Ditinjau dari aspek jaminan kesehatan menunjukkan bahwa kepuasan lulusan SMK 4 tahun berada pada kategori tinggi dan kepuasan lulusan SMK 3 tahun berada pada kategori menengah. Aspek keinginan pindah kerja baik menurut lulusan SMK 4 tahun maupun 3 tahun berada pada kategori rendah. Sedangkan untuk aspek lainnya, baik lulusan SMK 4 tahun maupun 3 tahun kepuasannya berada pada kategori tinggi.

\section{Pembahasan}

SMK program 4 tahun mupun program 3 tahun menggunakan kurikulum yang sama yakni kurikulum nasional. Kurikulum kedua program SMK tersebut disempurnakan dengan masukan dari DU/DI. Masukan dari DU/DI bermanfaat untuk merancang beberapa mata pelajaran tambahan untuk memperkaya pengetahuan siswa sesuai dengan kebutuhan pengguna lulusan. Mata pelajaran tambahan dikemas melalui muatan lokal berupa kompetensi yang dibutuhkan menurut perspektif DU/DI.

Selain pengembangan kurikulum, SMK dan DU/DI memiliki beberapa jenis kerja sama strategis. Kerja sama tersebut dapat berupa kerja sama perancangan kurikulum, kerja sama tempat praktik industri, kerja sama penempatan kerja, dan kerja sama penyaluran lulusan. Meskipun SMK 3 tahun dan SMK 4 tahun memiliki kerja sama dengan DU/DI yang hampir sama, tetapi SMK 4 tahun memiliki kerja sama yang lebih kuat dengan DU/DI. Hal ini dibuktikan dengan banyaknya DU/DI yang bekerja sama dan menjalin hubungan saling menguntungkan dengan pihak SMK 4 tahun. Intensitas kerja sama DU/DI dengan SMK program 4 tahun menunjukkan DU/DI memiliki ketertarikan lebih terhadap SMK 4 tahun karena dipandang memiliki kompetensi yang lebih matang.

Kompetensi lulusan SMK program 4 tahun dan 3 tahun ditinjau dari 11 indikator yaitu: kerja sama, disiplin, etika, keuletan, kemampuan teori, kemampuan praktik, rasa percaya diri, ketelitian, kreativitas, tanggung jawab, dan kepemimpinan. Secara keseluruhan SMK 4 tahun lebih unggul dari SMK
3 tahun yang ditinjau dari pandangan pihak sekolah dengan responden adalah kepala sekolah dan wakil kepala sekolah. Kompetensi lulusan SMK program 4 tahun menurut sekolah unggul pada tujuh aspek, yaitu: kerja sama, kedisiplinan, keuletan, kemampuan teori, rasa percaya diri, kreatifitas dan kepemimpinan. Keunggulan tersebut merupakan dampak dari lamanya pengalaman terjun ke lapangan yang diperoleh siswa melalui program PKL yang memakan waktu lebih lama dibandingkan SMK program 3 tahun. Berbekal dari keunggulan pada 7 aspek tersebut lulusan SMK 4 tahun dipandang memiliki kompetensi yang lebih baik dan lebih siap untuk memasuki lapangan pekerjaan.

Kinerja lulusan. Kinerja lulusan SMK ditinjau dari sudut pandang DU/DI sebagai "pengguna" lulusan secara keseluruhan SMK program 4 tahun menunjukkan lebih unggul daripada SMK program 3 tahun. Lulusan SMK program 4 tahun lebih unggul pada 8 aspek, yaitu kedisiplinan, keuletan, kemampuan teori, kemampuan praktek, rasa percaya diri, ketelitian, kreativitas, dan kepimpinan. Sama halnya dengan kompetensi lulusan menurut sekolah, keunggulan dalam 8 aspek tersebut merupakan dampak dari lamanya proses PKL yang membekali siswa dengan pengalaman kerja yang lebih banyak dan matang. Namun, selain unggul pada 8 aspek tesebut, lulusan SMK program 4 tahun tidak lebih baik pada aspek kerja sama. Rendahnya aspek kerja sama yang dimiliki lulusan SMK program 4 tahun disebabkan oleh tingginya kompetensi dan banyaknya pengalaman yang dimiliki lulusan SMK 4 tahun sehingga lulusan-lulusan tersebut mampu mengerjakan pekerjaan-perkerjaan yang diberikan secara mandiri.

Kompetensi guru menurut persepsi siswa dilihat dari bagaimana mengajar teori, mengajar praktik, disiplin mengajar, kehadiran mengajar, kemampuan membimbing karir siswa, serta kemampuan guru dalam membimbing belajar siswa. Kompetensi guru SMK program 4 tahun tidak lebih baik jika dibandingkan dengan kompetensi guru SMK program 3 tahun. Hal tersebut disebabkan oleh tingginya tuntutan kompetensi 
guru pada SMK program 4 tahun jika dibandingkan dengan guru SMK program 3 tahun, sehingga rendahnya tingat kompetensi guru pada SMK program 4 tahun pada penelitian ini bukan dikarenakan rendahnya kompetensi yang dimiliki guru tetapi tingginya kompetensi yang dibutuhkan untuk menjadi guru pada SMK program 4 tahun.

Kompetensi guru menurut kepala sekolah dan wakil kepala sekolah ditinjau dari bagaimana mengajar teori, mengajar praktik, mendapatkan penghargaan, menghasilkan karya teknologi, komitmen dalam membimbing siswa, melakukan penelitian, menghasilkan bahan ajar, mengembangkan lab/bengkel, serta membangun kerja sama dengan DU/DI. Kometensi guru SMK program 4 tahun lebih baik daripada guru SMK program 3 tahun dalam menghasilkan bahan ajar, mengembangkan bengkel serta membangun kerja sama dengan dunia usaha dan dunia industri karena guru pada SMK program 4 tahun dituntut untuk mampu memberikan pelayanan yang lebih optimal kepada peserta didik dalam rangka membekali peserta didiknya dengan pengetahuan dan pengalaman yang matang. Selain itu hasil penelitian ini juga menunjukkan bahwa komitmen guru SMK program 4 tahun dalam membimbing peserta didiknya lebih baik daripada SMK program 3 tahun. Meskipun dinyatakan lebih baik, masih terdapat 11\% guru SMK program 4 tahun yang dinyatakan memiliki kompetensi yang tidak baik pada kedua program.

Aspek sarana dan prasarana ditinjau dari kondisi/kualitas sarana dan prasarana yang dimiliki dan kebutuhan terhadap sarana dan prasarana tersebut. Adapun aspekaspek yang menjadi fokus penelitian ini yaitu ruang kelas teori, laboratorium, bengkel, lahan praktikum, teaching factory, bengkel kerja sama industri, tempat uji kompetensi (TUK), peralatan uji kompetensi, dan bahan praktikum. Sarana dan prasarana SMK 4 tahun menunjukan $80 \%$ dengan kategori baik dan 20\% dengan kategori cukup baik. Kebutuhan sarana dan prasarana SMK 4 tahun adalah $75 \%$ cukup dan $25 \%$ tidak cukup.
Sarana prasana yang dimiliki SMK program 4 tahun memiliki kualitas yang lebih baik jika dibandingkan dengan SMK program 3 tahun, namun kecukupan sarana prasarana tidak lebih baik daripada SMK program 3 tahun. Hal tersebut disebabkan karena kebutuhan sarana prasarana yang lebih memadai pada SMK program 4 tahun untuk menyelenggarakan pendidikan kejuruan dengan masa studi lebih lama. Oleh karena itu adanya perbaikan sarana dan prasarana merupakan hal yang sangat baik untuk meningkatkan keterampilan siswa.

Kondisi pada SMK program 3 tahun (kualitas baik namun kecukupan mencapai 80\%) mengarah pada dua kemungkinan apabila kebutuhan masih dalam kondisi yang cukup tetapi kualitas dalam keadaan yang baik tetapi butuh perbaikan, maka dapat diindikasikan bahwa peralatan yang digunakan di SMK 3 tahun adalah peralatan yang sudah out of date atau ketinggalan zaman dan membutuhkan pembaruan sehingga peralatan yang dimiliki tidak hanya cukup dari segi kuantitas tetapi juga memiliki kondisi yang baik dari segi kualitas.

Sumber pembiayaan sekolah SMK 3 tahun lebih banyak daripada SMK 4 tahun. Hal ini ada beberapa faktor yang mempengaruhi oleh fasilitas SMK 4 tahun, khususnya sarana prasarana praktik lebih baik dari pada SMK 3 tahun, sehingga SMK 3 tahun perlu mendapatkan dana lebih untuk pengadaan dan perawatan sarana dan prasarana penunjang pembelajaran. Sarana prasarana yang sudah memadai di SMK 4 tahun secara keseluruhan telah memiliki alat dan bahan serta bengkel/laboratorium yang lengkap, sedangkan SMK 3 tahun dalam hal sarana prasarana masih kurang sehingga membutuhkan dana yang banyak untuk menunjang pembelajaran. Data sekolah yang sudah diobservasi SMK 3 tahun ada 14 sumber dana dan SMK 4 tahun ada 7 sumber dana.

Secara keseluruhan performance lulusan SMK 4 tahun lebih unggul daripada lulusan SMK 3 tahun. SMK 4 tahun memiliki lebih banyak lulusan yang bekerja dengan masa tunggu lebih singkat (0-3 bulan) dan gaji yang lebih tinggi (1,1-5 juta rupiah) 
jika dibandingkan dengan SMK program 3 tahun. Fenomena tersebut disebabkan oleh masa belajar SMK program 4 tahun yang lebih lama dibandingkan SMK program 3 tahun. Masa studi yang lebih panjang menyebabkan pengalaman dan pengetahuan lebih matang. Kompetensi yang dipelajari SMK 4 tahun juga berdampak pada masa tunggu bekerja sekitar 0-3 bulan. Sebaliknya, berbeda dengan SMK 3 tahun yang masa tunggunya lebih lama sekitar 0-12 bulan. Tetapi jiwa wirausaha SMK 3 tahun lebih baik daripada SMK 4 tahun dikarenakan keterampilan yang dipelajari selama 3 tahun lebih fleksibel bagi lulusan untuk berwirausaha, bekerja atau melanjutkan ke perguruan tinggi. Sedangkan lulusan SMK 4 tahun lebih dominan memilih bekerja atau melanjutkan ke perguruan tinggi.

Kepuasan kerja lulusan SMK ditinjau dari 9 aspek yaitu penghasilan, suasana kerja, hubungan dengan atasan, hubungan sesama teman, keinginan pindah kerja, kepuasan kerja, fasilitas kerja, lingkungan kerja, dan jaminan kesehatan. Berdasarkan banyaknya aspek kepuasan kerja yang berada pada kateori tinggi, maka lulusan SMK program 4 tahun kepuasan kerjanya lebih baik daripada lulusan SMK program 3 tahun. Hasil pengamatan menunjukkan bahwa SMK 3 tahun 56\% pada kategori tinggi, 33\% pada kategori menengah, dan $11 \%$ pada kategori rendah. Sedangkan untuk kepuasan kerja lulusan SMK 4 tahun adalah $67 \%$ pada kategori tinggi, 22\% pada kategori menengah, dan $11 \%$ pada kategori rendah.

Delapan aspek kepuasan kerja lulusan SMK program 4 tahun dan 3 tahun berada pada kategori yang sama yaitu tinggi, menengah, dan rendah. Jika dilihat lebih rinci, dari 8 aspek kepuasan yang mekiliki kategori yang sama, maka kepuasan kerja lulusan SMK program 3 tahun lebih baik daripada kepuasan kerja lulusan SMK program 4 tahun dalam 5 hal yaitu: (1) suasana kerja; (2) hubungan dengan atasan; (3) hubungan sesama teman; (4) kepuasan kerja; dan (5) lingkungan kerja. Jika dilihat dari aspek penghasilan, baik lulusan SMK program 4 tahun maupun 3 tahun kepuasannya berada pada kategori menengah, sedangkan keinginan pindah kerja termasuk rendah. Pada aspek jaminan kesehatan, kepuasan kerja lulusan SMK program 4 tahun lebih baik daripada lulusan SMK program 3 tahun. Kepuasan pengguna lulusan terhadap lulusan SMK program 3 tahun dapat disebabkan oleh rendahnya upah lulusan SMK 3 tahun sehingga pengguna lulusan cenderung lebih menyukai lulusan SMK program 3 tahun dari segi pembiayaan.

\section{Simpulan}

Berdasarkan hasil penelitian dan pembahasan, maka dapat disimpulkan beberapa hal yaitu sebagai berikut. Pertama, kurikulum SMK 3 tahun dan SMK 4 tahun secara umum memiliki per-samaan yaitu menggunakan kurikulum na-sional yang dikembangkan berdasarkan keperluan dunia industri dengan melibatkan industri pasangan.

Kedua, kompetensi lulusan SMK 4 tahun lebih baik dibanding kompe-tensi lulusan SMK 3 tahun apabila ditinjau dari persentase kompetensi lulusan bahwa kompetensi lulusan SMK 4 tahun dinyatakan 100\% masuk dalam kateogri sangat baik, sedangkan kompetensi lulusan SMK 3 tahun dinyatakan 64\% masuk dalam kategori sangat baik dan 36\% masuk dalam kategori baik.

Ketiga, kinerja lulusan SMK program 4 tahun menurut pendapat industri lebih baik dibanding kinerja lulusan SMK program 3 tahun. Lulusan SMK 4 tahun memiliki keunggulan dalam 8 hal yaitu: disiplin, keuletan, kemampuan teori, kemampuan praktik, rasa percaya diri, ketelitian, kreativitas, dan kepemimpinan. Lulusan SMK program 3 tahun memiliki keunggulan dalam aspek kerja sama sesama siswa.

Keempat, kompetensi guru SMK 4 tahun memiliki keunggulan dalam membimbing siswa, menghasilkan bahan ajar, mengembangkan bengkel, dan membangun kerja sama dengan DU/DI. Kelima, kondisi sarana dan prasarana SMK 4 tahun dinyatakan $80 \%$ masuk dalam kategori baik dan $20 \%$ masuk dalam kategori cukup baik dengan jumlah kebutuhan 75\% masuk dalam kategori cukup. Kondisi sarana dan prasa-

Evaluasi Implementasi Kebijakan Sekolah Menengab ... - 225 Soenarto, Muhammad M. Amin, , Kumaidi 
rana SMK 3 tahun dinyatakan 60\% masuk dalam kategori baik, 20\% masuk dalam kategori cukup baik, dan 20\% masuk dalam kategori kurang baik dengan jumlah kebutuhan yaitu $80 \%$ masuk dalam kategori cukup.

Keenam, kompotensi lulusan SMK 4 tahun lebih unggul daripada SMK 3 tahun karena SMK 4 tahun disiapkan mengembangkan keterampilan selama 4 tahun sehingga kompetensinya lebih terampil. Ketujuh, pembiayaan SMK 4 tahun ditopang oleh pemerintah daerah dan alumni, sedangkan SMK 3 tahun hanya dibiayai oleh siswa.

Kedelapan, dampak program SMK 4 tahun lebih efektif dari pada SMK 3 tahun dilihat dari lama masa tunggu dan jumlah lulusan yang bekerja. Selain itu penghasilan lulusan SMK 4 tahun cenderung lebih tinggi daripada lulusan SMK 3 tahun. Kesembilan. kepuasan kerja lulusan SMK program 4 tahun lebih baik daripada lulusan SMK program 3 tahun.

Sesuai dengan kesimpulan tersebut maka dapat dirumuskan beberapa rekomendasi yaitu: (1) perlu dibedakan struktur kurikulum SMK 4 tahun dan SMK 3 tahun dengan memperhatikan Kerangka Kualifikasi Nasional Indonesia (KKNI) dan jabatan di dunia kerja; (2) program praktik industri SMK 4 tahun supaya dikembangkan secara sistematik sesuai tahapan waktu praktik, efektif, dan efisien dalam perencanaan, pelaksanaan, dan evaluasinya agar hasilnya optimal; (3) perlu dilakukan evaluasi bersama pihak sekolah dan industri dalam pelaksanaan praktik industri untuk mendapatkan pola praktik industri yang lebih efektif dan efisien; (4) kualifikasi kompetensi lulusan SMK 4 tahun lebih baik daripada lulusan SMK 3 tahun sehingga pengakuan dan penghargaan terhadap lulusan SMK 4 tahun sebaiknya diberikan lebih baik dari lulusan SMK 3 tahun; (5) sebaiknya lulusan SMK program 4 tahun tetap dapat menjalin kerja sama dengan rekan kerja yang lain, meskipun sudah memiliki kompetensi memadahi atau lebih baik daripada lulusan SMK program 3 tahun; (6) sebaiknya guru SMK 4 tahun dan SMK 3 tahun selalu mengikuti perkembang- an teknologi dengan mengikuti program magang di industri secara periodik; dan (7) Keunggulan program SMK 4 tahun yang mencakup perawatan sarana dan prasarana, masa tunggu, kompetensi lulusan, dan partisipasi alumni dalam pemberian bantuan dana agar dapat diadopsi oleh program SMK lainnya.

\section{Daftar Pustaka}

Alisjahbana, A. S. (2014). Menteri PPN/Kepala Bappenas, tantangan kependudukan, ketenagakerjaan, dan SDM Indonesia menghadapi globalisasi khususnya masyarakat ekonomi Asean: "Arah kebijakan dan program di bidang kependudukan, ketenagakerjaan dan sumber daya manusia menghadapai glob. In Makalah. Jakarta.

Badan Pusat Statistik. (2014). Berita resmi badan pusat statistik. Retrieved from https://www.bps.go.id/

Balogh, T. (1969). Education and agrarian progress in developing countries. In $\mathrm{K}$. Hufne \& J. Naumann (Eds.), Economics of Education in transition (pp. 259-68). Stuttgart: Ernst Klett.

Barro, R. (2001). Education and economic growth. In J. F. Helliwell (Ed.), The Contribution of Human and Social Capital to Sustained Economic Growth and WellBeing. OECD.

Depdiknas. Undang-Undang Nomor 20

Tahun 2003 tentang Sistem Pendidikan Nasional (2003). Jakarta.

Djojonegoro, W. (1998). Pengembangan sumberdaya manusia melalui sekolah menengah kejuruan (SMK). Jakarta: PT Balai Pustaka.

Habibie, B. J. (2013). Sumber daya manusia masyarakat madani. In Pidato KONASPI ke 7. Yogyakarta.

Pardjono, P., Sugiyono, S., \& Budiyono, A. (2015). Developing a model of competency and expertise certification tests for vocational high school 
students. Research and Evaluation in

Education, 1(2), 129.

https://doi.org/10.21831/reid.v1i2.65

17

Psacharopoulos, G. (1997). Vocational education and training today: challenges and responses 1. Journal of Vocational Education \& Training, 49(3), 385-393. https://doi.org/10.1080/13636829700 200022

Supriadi, D. (2002). Sejarah pendidikan teknik dan kejuruan di Indonesia: Membangun manusia produktif. Jakarta: Departemen Pendidikan Nasional, Direktorat Jenderal Pendidikan Dasar dan Manengah, Direktorat Pendidikan Menengah Kejuruan. 